Article

\title{
Blue-Green Playscapes: Exploring Children's Places in Stormwater Spaces in Augustenborg, Malmö
}

\author{
Misagh Mottaghi ${ }^{1,2, *}$, Maria Kylin ${ }^{3}$, Sandra Kopljar ${ }^{1}$ and Catharina Sternudd ${ }^{1}$ \\ ${ }^{1}$ Department of Architecture and Built Environment, Lund University, 22100 Lund, Sweden; \\ E-Mails: misagh.mottaghi@arkitektur.Ith.se (M.M.), sandra.kopljar@arkitektur.Ith.se (S.K.), \\ catharina.sternudd@arkitektur.lth.se (C.S.) \\ 2 Sweden Water Research, Ideon Science Park, 22370 Lund, Sweden \\ ${ }^{3}$ Department of Landscape Architecture, Planning and Management, Swedish University of Agricultural Science, \\ 23053 Alnarp, Sweden; E-Mail: maria.kylin@slu.se \\ * Corresponding author
}

Submitted: 21 December 2020 | Accepted: 12 March 2021 | Published: 25 May 2021

\begin{abstract}
The urbanisation of cities increases the demands on, and complexity of, urban land use. Urban densification is challenging urban green space. Cities have responded to this challenge by adopting a multiple-use strategy where different functions share space. Shrinking open space has to contain solutions for everyday functions such as bicycle parking, waste sorting, blue-green stormwater systems, and playscapes. Values and functions that can reinforce and amplify each other are therefore of interest to study. The present article explores the possibilities for blue-green solutions (BGS) to be used as part of children's playscapes. BGS are aboveground, ecological stormwater facilities, introduced to prevent flooding and support biodiversity while adding recreational and aesthetic qualities to the urban environment. The objective is to discuss the extent to which ecological and social values can reinforce each other in terms of encouraging children to engage with BGS natural elements. The researchers have studied the Augustenborg residential neighbourhood in Malmö. The area was primarily investigated through a postal survey, which identified a remodelled park with a floodable sunken lawn as a potentially attractive area for children's activities. The park was analysed as a potential playscape and supported by on-site observations. The study shows that even if BGS largely meet children's play values, due to existing socio-spatial structures, children are not using the offered play features. The article discusses the results in terms of how stormwater management may enhance the actualisation of play potentials in children's everyday living environment.
\end{abstract}

\section{Keywords}

affordance; blue-green solutions; children; everyday life; play possibilities; urban design; urban open space; urban water management

Issue

This article is part of the issue "Planning for Rapid Change in Cities" edited by Karina Landman (University of Pretoria, South Africa).

(C) 2021 by the authors; licensee Cogitatio (Lisbon, Portugal). This article is licensed under a Creative Commons Attribution 4.0 International License (CC BY).

\section{Introduction}

The world's urban population is increasing dramatically (UN, 2019). Cities are not only getting denser in terms of population but also more compact to include more dwellings and services. The densification of cities is usu- ally presented as a sustainable way of locally handling a growing urban population, for example by reducing $\mathrm{CO}^{2}$ emissions from travel or by offering proximity to everyday destinations (Jenks, Burton, \& Williams, 1996). When urban areas are densified, urban open space is put under pressure and needs to be adapted for multiple uses. 
This may drive different forms of inequality and issues such as how different user groups relate to certain areas and increase the complexities found in urban space.

Changing urban open space largely challenges possibilities for children's outdoor play by reducing the amount of urban green spaces and natural features in cities. In Sweden, families with young children are changing residential habits and residing more in inner cities (Karsten, 2014; Karsten \& Felder, 2015; Statistics Sweden, 2005). Places and areas traditionally allocated for children's play, such as schoolyards and neighbourhood parks, are being used for other building purposes (Kylin \& Bodelius, 2015; Nordström, 2014; Statistics Sweden, 2018). The importance of play for children's physical health, social development, and general well-being is pointed out in several research studies. Outdoor play enhances physical activity in children and thus promotes physical health, helping to prevent issues such as obesity and underdeveloped motoric skills (Martensson et al., 2014; Pagels et al., 2014). The activity of play also has bearing on the social and psychological aspects that children have to practice (Berg, 1992). Studies about the role of greenery, nature, and other environmental aspects that provide the opportunity for play show that children's engagement with nature also affects their health, cognitive development, and abilities in a positive way (Chawla, 2015; Faskunger, 2007). It takes space to find places to play, and these outdoor spaces for children are diminishing in the discourse of contemporary urban planning.

Climate change is one of several urban challenges calling for the transition of urban space to improve resilience. Extreme rain events are expected to occur with higher intensity and frequency (UN Office for Disaster Risk Reduction, 2019). Blue-green solutions (BGS) are surface open solutions complementary to underground stormwater pipe facilities to handle urban flooding. Malmö municipality accelerated the implementation of BGS after serious flooding on 31 August 2014. The retrofitting of urban open space, such as parks and streets, to accommodate BGS was enacted through the (re)development of urban areas. Such adaptations are adding to the complexity of rapid urban changes (i.e., Mottaghi, Kärrholm, \& Sternudd, 2020), putting pressure on urban green space and potentially leaving less space for children.

BGS can be designed and incorporated into the urban open space in many different ways. BGS that imply green elements and natural features could potentially amplify the possibility to co-create play spaces. However, BGS can also be designed and executed in a way that takes away space from children's recreational places. This highlights a potential conflict between goals in ecological and social sustainable development and emphasises the necessity to study the play possibilities generated by BGS in urban space.

This article explores the possibilities for BGS to be used as part of children's playscapes in the Augustenborg neighbourhood in Malmö. The objective is to understand the extent to which ecological and social values can reinforce each other in terms of creating environments with affordances for children's play. We draw on 'affordance' as a concept to concentrate on interrelated qualities and features of an environment, while investigating possibilities for playful movements that BGS in Augustenborg offer to younger (3-6 years old) and middle ( $7-10$ years old) children. The area is primarily investigated through a postal survey, to recognise the best potential place for children's outdoor activities. The identified area-the neighbourhood park - has subsequently been analysed with a reviewed method to assess the possibilities to play and with on-site observations to realise different aspects that influence the actualisation of those possibilities.

\section{Theoretical Background}

James J. Gibson (1979) introduced the concept of affordance to account for the possibilities for action that an environment offers to animals, including humans. A developed concept of affordance includes responses to sequentially revealed offers for action as in 'nested affordances' (Gaver, 1991). Affordances can also be considered as dependent on personal history or imagination as in the concept 'carried affordances' (Kopljar, 2016). The concept of affordance is applicable to study that which is directly present in an environment. Heft (1988) drew on Gibson's affordance and focused more on the characters of physical affordances of the environment. He outlined a transactional worldview that accounts for the ever-changing interaction between humans and environments (Heft, 2013). Included in this, he studied physical affordances for children. While affordance is always there to be perceived, his work reveals how good children are at perceiving affordances, since they are open and "less pervasive as compared to adults" (Heft, 1988, p. 31). Heft explains affordances as "perceptible properties of the environment that have functional significance for an individual" (Heft, 2010, p. 18) and recognises the theory as a suitable one to study "interrelated qualities of environments and environmental features that often fail to appear in conventional accounts of environmental perception" (Heft, 2010, p. 22). He describes affordance as a relational concept that is dependent on the physical properties of both the environment and the user (Heft, 1989). The final action depends on how individuals connect to the environment. Heft (1989) differs between 'potential affordances' (action possibilities) and 'actualised affordances' (utilised possibilities, revealed when actions are taken). While there are a variety of potential affordances, depending on how individuals detect them, there are a limited number of actualised affordances. Heft's work is later followed by other researchers (i.e., Kytta, 2004; Lerstrup \& Konijnendijk van den Bosch, 2017) focusing on characterising an ideal environment where children are likely to actualise multiple affordances. In this article, we borrow affordance 
theory to shift from looking at BGS as just ecological pieces of the urban landscape to the attached pieces connected to the surrounding environment.

\section{Methodology}

We initiated our study with Augustenborg urban housing area (Figure 1). The importance of the research was revealed through an ethnographic pilot study in 2017, but we will not go through that material in this article. The study included observations and unplanned interviews, looking at how different actors experience BGS through movements and sensory engagement. The mentioned study disclosed the nexus between the materiality of BGS and the experiential environment. The data collection, for the present article, started with a postal survey in Winter 2018, which helped us select a more narrow and focused study area. Based on the result, one area (the park) was identified as a potential play area and was analysed concerning different features of BGS based on the classification of outdoor environment for children proposed by Heft (1988) and Lerstrup and Konijnendijk van den Bosch (2017). Later in Summer 2020, on-site observations were carried out as a complement to the previous methods.

\subsection{The Augustenborg Neighbourhood}

Our case study is an administrative district in Malmö within Sweden called Augustenborg. Malmö went through an economic crisis in the late 1980s after its main industries collapsed. Thus, the city followed new development strategies by shifting towards neoliberal and sustainable planning strategies (Baeten, 2012;

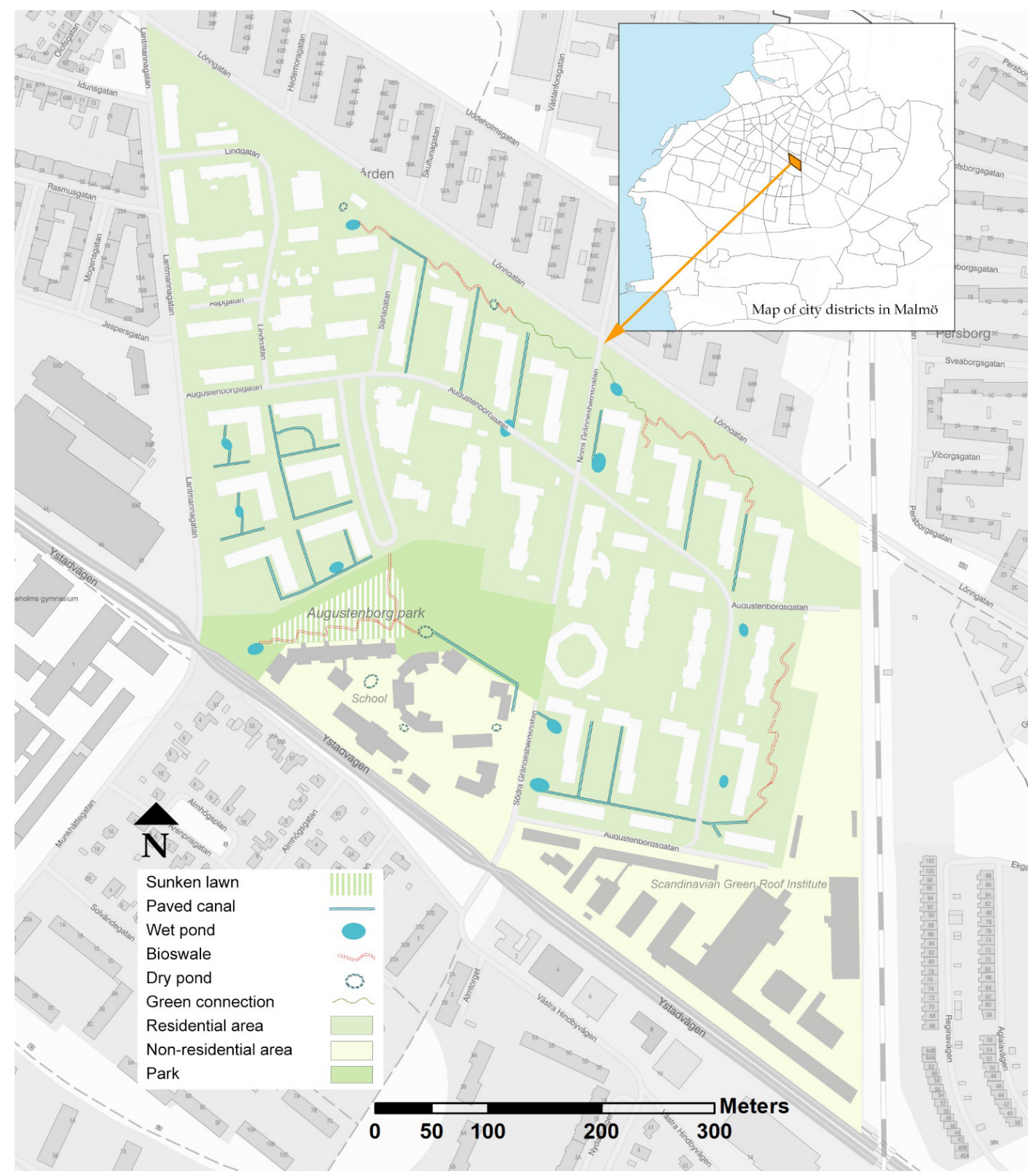

Figure 1. Map of Augustenborg showing BGS in urban open space. Source: Mottaghi et al. (2020). 
Holgersen \& Malm, 2015). Augustenborg is an urban neighbourhood accommodating 3,875 inhabitants within 1,887 households (Malmö stad, 2019; updated on 27 September 2019). The neighbourhood was planned as a post-war green housing area in 1947 and was developed entirely by the municipal housing company MKB from 1948 to 1952 . The housing blocks are mostly 3-5 story and are open block type, providing a range of rental apartments (Tykesson \& Ingemark Milos, 2001). The residential landscape is connected to the neighbourhood park. The original intention with the interconnecting park in Augustenborg was to let the green areas expand from the central park into the spaces between the residential buildings and in that way erase the borders between plots used for housing and the park area (Tägil, 2020). In the 1970s, the area lost its popularity as a desirable living area. Social problems such as criminality, unemployment, and changes in the requirement of housing standards appeared to evolve and people started to move out of the area.

In 1998, Eco City Augustenborg was proposed as a redevelopment project to enhance the social and ecological status of the area. Since the area previously suffered from the consequences of flooding, the main design concept was to improve the management of urban flooding through embedding BGS on its already green landscape. The neighbourhood park was largely remodelled into a floodable sunken lawn. Other objectives were to improve waste management and apply participatory development and environmental approaches by involving the community (Stahre, 2008). Despite the introduction of participatory initiatives such as Gnistan, a social meeting place for children who are 6-14 years old that organises activities both indoors and outdoors, and Växtvärk, with pedagogical and gardening activities for children, the initiatives were not focusing on the potentials of BGS as such (Martinez Avila, Hanson, \& Alkan Olsson, 2020). We chose this specific case because it is a pioneer retrofitting urban project in which the landscape was redeveloped to accommodate the urban runoff from heavy rainfalls through different types of BGS. The project has been proven to technically function well (Sörensen \& Emilsson, 2019). Moreover, it is a well-known test-bed project for urban resilience in
Europe and it won the UN World Habitat Award in 2010 because of its approach to sustainable development. Some research has been done regarding the technicality of BGS in the Augustenborg area (Emilsson \& Sörensen, 2020; Nilsson, Nilsson, \& Persson, 2020). However, the intersection between the blue-green infrastructure and potential social values for children remains unexplored.

\subsection{Postal Survey}

An extensive postal survey, designed mainly for other inquiries, was used to collect information from inhabitants in Augustenborg about what BGS actually mean to them in their everyday life. The questionnaire was designed mostly in the form of Likert scale questions, asking the inhabitants about their use, proximity to, and experience of three types of BGS: a sunken lawn, wet ponds, and paved canals implemented in the neighbourhood. Two questions were included to gain a general impression about which types of BGS are possibly the most attractive to children. These questions were asked separately for each type of BGS. Also, the demographic section asked about the number of children and adults in each household. Table 1 shows the three included children-related items. The questionnaire was sent to all households in Augustenborg in November 2018 and collected back by the end of the year. It was answered by 328 households.

\subsection{Assessment Tool}

According to the survey (explained in Section 4), the sunken lawn which covers a large part of Augustenborg Park was recognised as the area most frequented by children. Hence, for our study area, we selected an area of the park with a variety of terrain changes and vegetation. This area includes BGS with ponds, bioswales, and canals interplaying with the sunken lawn, together with hills and different vegetation. The area is surrounded by a school, a kindergarten, a musical playground, a dog park, and sports fields (Figures 2 and 3 ).

To initiate the discussion on play possibilities offered by BGS in the park, the research team searched for affordance-based assessment tools. By observing a

Table 1. Children-related items in the questionnaire.

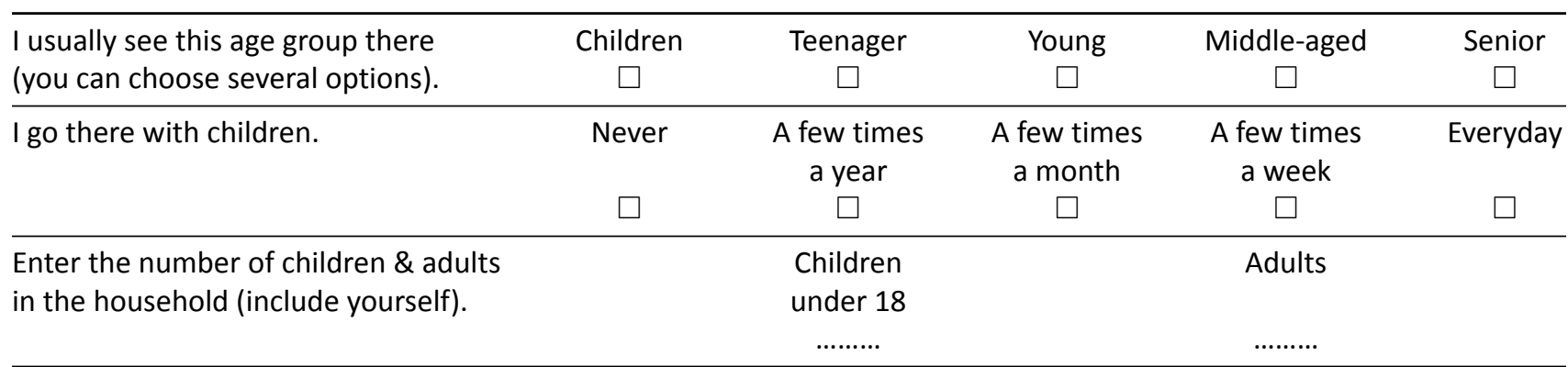

Note: The first two questions were asked separately for the sunken lawn area (in the park), wet ponds, and paved canals located in Augustenborg outdoor environment. 


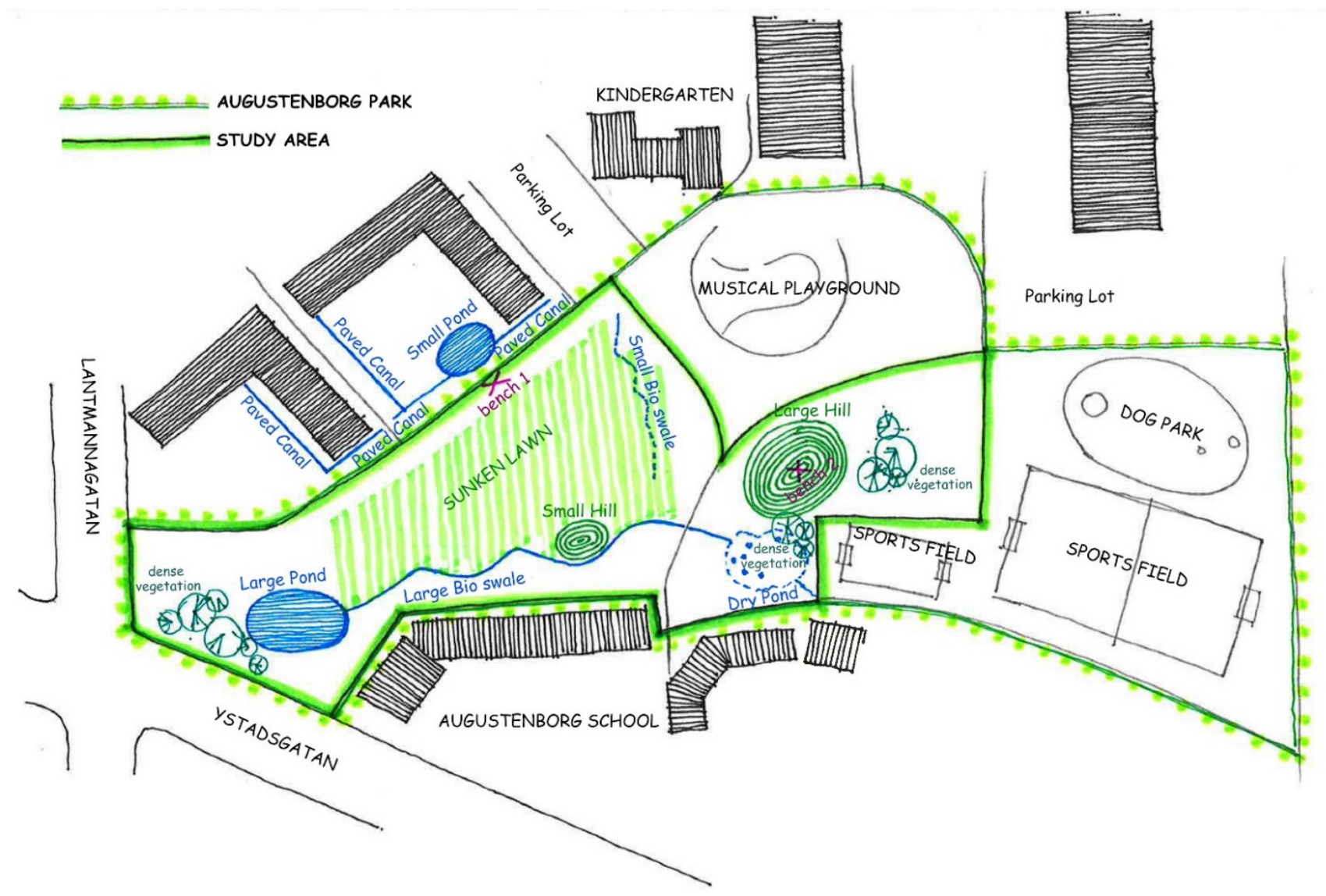

Figure 2. Augustenborg park setting.

nine-year-old boy in his daily life, Heft (1988) developed a functional taxonomy for children's outdoor environment by applying the concept of affordance. He was inspired by the five affording features formulated by Gibson (1979) as Places, Attached objects, Detached objects, Substances, and Events. Heft's work inspired other researchers to develop several assessment tools for children's outdoor environments (i.e., Refshauge, Stigsdotter, Lamm, \& Thorleifsdottir, 2015; Woolley \& Lowe, 2013). Lerstrup and Konijnendijk van den Bosch (2017) developed an assessment tool for the outdoor environment to evaluate meaningful action possibilities for younger (3-6 years old) children. By meaning- ful action possibilities, they mean the possibilities for actions that are perceptible and important to children. The tool evolved from the functional significance that was already being proposed by Heft (1988; Figure 4). The assessment tool contains functional categories and summarises features for analysing affordances of outdoor settings by developing the classes that have already been highlighted by Gibson and Heft. Lerstrup and Konijnendijk van den Bosch (2017) underlined the formbased features of open ground, sloping terrain, shielded places, rigid fixtures, moving fixtures, loose objects, loose material, water, creatures, and fire playing roles for meaningful actions to be carried out by younger children.
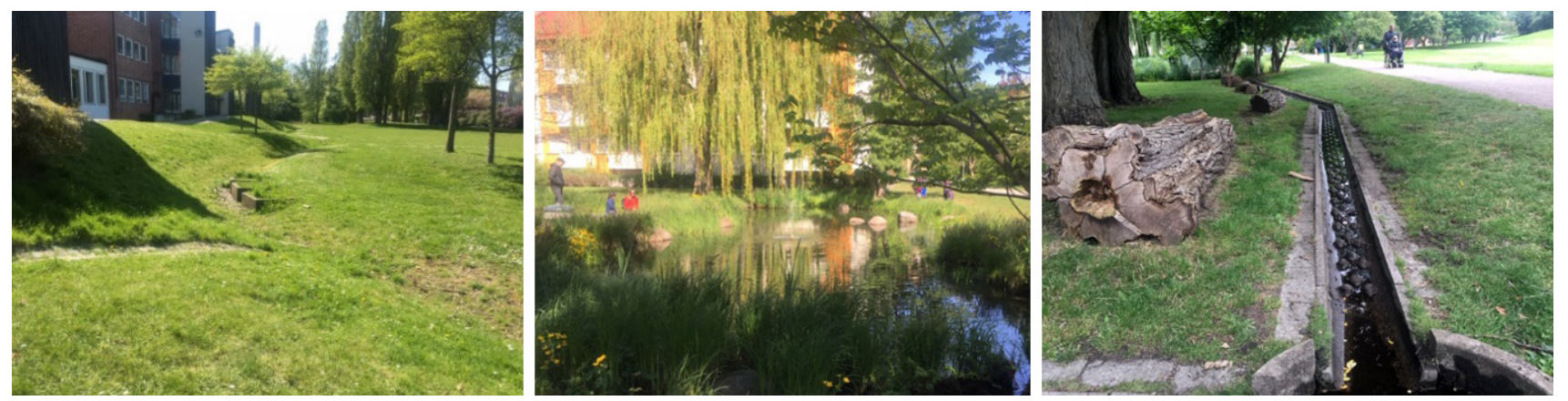

Figure 3. BGS in Augustenborg. From left to right: large bioswale; small pond along the park; and concrete canal along the park. 


\begin{tabular}{|c|c|c|c|c|}
\hline $\begin{array}{l}\text { Affording features } \\
\text { (Gibson, 1979) }\end{array}$ & $\begin{array}{l}\text { Functional classes } \\
\text { of outdoor } \\
\text { features (Heft, } \\
\text { 1988) }\end{array}$ & Activities $^{\mathrm{a}}$ (Heft, 1988) and(Lerstrup et al.) & $\begin{array}{l}\text { Classes of } \\
\text { outdoor } \\
\text { features } \\
\text { (Lerstrup et al.) }\end{array}$ & $\begin{array}{l}\text { Key activities }{ }^{\mathrm{b}} \\
\text { (Lerstrup et al.) }\end{array}$ \\
\hline \multirow[t]{4}{*}{ Places (Immobile) } & $\begin{array}{l}\text { Flat, relatively } \\
\text { smooth surface }\end{array}$ & $\begin{array}{l}\text { Walking, running, cycling, (skating, } \\
\text { skateboarding), driving, playing ball, song } \\
\text { games, games in bigger groups }\end{array}$ & Open ground & Run, drive, walk \\
\hline & $\begin{array}{l}\text { Relatively smooth } \\
\text { slope }\end{array}$ & $\begin{array}{l}\text { (Coasting down), rolling/sliding/running down, } \\
\text { rolling objects down, jumping down, climbing } \\
\text { up; for ditches: jumping over, building over, } \\
\text { hiding in, sitting in }\end{array}$ & Sloping terrain & $\begin{array}{l}\text { Roll, slide, } \\
\text { clamber }\end{array}$ \\
\hline & Shelter & $\begin{array}{l}\text { Microclimate, prospect/refuge, privacy, hiding in, } \\
\text { lying in, sitting in }\end{array}$ & Shielded places & Hide, as frame \\
\hline & Aperture & $\begin{array}{l}\text { Locomoting from one place to another, looking } \\
\text { and listening to adjacent places }\end{array}$ & & \\
\hline \multirow{3}{*}{$\begin{array}{l}\text { Attached Objects, } \\
\text { (Immobile, } \\
\text { countable) }\end{array}$} & Attached object & $\begin{array}{l}\text { Sitting-on, jumping-on/over/down-from, } \\
\text { running around, hiding behind, building on }\end{array}$ & Rigid fixtures & $\begin{array}{l}\text { Climb, balance, } \\
\text { jump }\end{array}$ \\
\hline & Climbable object & $\begin{array}{l}\text { Exercise/mastery, looking out from, passing } \\
\text { from one place to another, lying-on, climbing, } \\
\text { balancing-on, hanging by arms, hanging in legs }\end{array}$ & & \\
\hline & $\begin{array}{l}\text { Non-rigid attached } \\
\text { object }\end{array}$ & $\begin{array}{l}\text { Swinging-on, swaying-in, seesawing-on, looking } \\
\text { out from, spinning, sitting in, lying on, springy } \\
\text { jumping }\end{array}$ & Moving fixtures & $\begin{array}{l}\text { Swing, sway, } \\
\text { seesaw, spin }\end{array}$ \\
\hline $\begin{array}{l}\text { Detached Objects } \\
\text { (Movable, } \\
\text { countable) }\end{array}$ & $\begin{array}{l}\text { Graspable/ } \\
\text { detached object }\end{array}$ & $\begin{array}{l}\text { Drawing, scratching, throwing, hammering, } \\
\text { batting, (spearing, skewering), digging, } \\
\text { cutting, tearing, crumbling, squashing, } \\
\text { building of structures, picking, gathering, } \\
\text { sorting, arranging, making patterns, as } \\
\text { accessories, as tools, throwing, sawing, carving, } \\
\text { bending, breaking, thatching, crushing, hacking, } \\
\text { tasting, eating, kicking in, walking on foot } \\
\text { extensions }\end{array}$ & Loose objects & $\begin{array}{l}\text { Arrange, modify, } \\
\text { as tools, props, } \\
\text { treasures }\end{array}$ \\
\hline \multirow[t]{2}{*}{$\begin{array}{l}\text { Substances } \\
\text { (Movable, not } \\
\text { countable) }\end{array}$} & Mouldable material & $\begin{array}{l}\text { Construction of objects, pouring, modification of } \\
\text { its surface features, moving around, moulding, } \\
\text { smearing, kneading, smashing, digging-in, } \\
\text { raking, sifting, kicking in, gliding in }\end{array}$ & Loose material & $\begin{array}{l}\text { Dig, move, } \\
\text { mould, smear }\end{array}$ \\
\hline & Water & $\begin{array}{l}\text { Splashing, pouring, floating objects, (swimming, } \\
\text { diving, boating), fishing, mixing with other } \\
\text { materials to modify their consistency, } \\
\text { gathering, throwing into, jumping in, floating } \\
\text { with the stream, building of dams }\end{array}$ & Water & $\begin{array}{l}\text { Pour, mix, splash, } \\
\text { float }\end{array}$ \\
\hline \multirow[t]{2}{*}{ Events (Changes) } & & Following, catching, caring for & Creatures & $\begin{array}{l}\text { Look for, handle, } \\
\text { care }\end{array}$ \\
\hline & & $\begin{array}{l}\text { Feeding, poking with sticks, sitting by, follow } \\
\text { cooking, drawing with charcoal, putting out }\end{array}$ & Fire & $\begin{array}{l}\text { Feed, look after, } \\
\text { sit by }\end{array}$ \\
\hline
\end{tabular}

aRegular font: Heft and Lerstrup et al. In brackets: Heft only. Italics: Lerstrup et al. only.

bey activities $=$ distinctive and attractive activities for each class.

Figure 4. Activities and classes of outdoor features. Source: Lerstrup and Konijnendijk van den Bosch (2017, p.54).

We borrow the taxonomy to explore such materially present offers for play-affordance features-by the BGS in the park. We assessed the area with the aforementioned tool to identify the children's possibility for play, offered by the BGS.

\subsection{On-Site Observations}

As researchers who are not users of the area on an everyday basis, we needed to move from looking at a place in our study towards exploring children's being in the place interacting with BGS features. To explore whether children interact with BGS affordance features and utilise the play possibilities, observations were carried out in Summer 2020 on dry days of Thursday 2020.07.16, 14:30-15:30; Friday 2020.07.17, 13:00-15:00; Saturday 2020.07.18, 17:00-18:00; Sunday 2020.07.19, 15:0016:00; and a rainy day of 2020.08.28, 15:00-16:00. During the six hours of observation, 63 children were observed, of which 34 are estimated as younger (3-6 years old) children and 29 are rated as middle ( $7-10$ years old) children. Coming up with an exact age of the children without carrying interviews is impossible, and since we intended to minimise influencing the user behaviour, we estimated the belonging age group without approaching them directly, based on size, abilities, and skills.

Since the studied group was composed of children, we tried to avoid taking photos or filming, which is restricted by law in Sweden. The observational methods used in this study include making field notes, sketches, and tracing maps, to understand how children move around in the park, as well as which features of BGS children include in their movement and play. The methods allow documenting activities and behaviours with minimal researcher interference. Tracing allows registering people's movements in limited spaces with lines on a plan of the studied area (Gehl \& Svarre, 2013). It thus maps spatial movement but is limited when it comes to mapping the duration of movements, as well as stops or significant tempo changes.

Throughout the observation, we also used complementary methods, such as taking notes and doing sketches. The combination of methods not only allowed us to start from an incident and explore related 
associations, but it also helped us to move from individual interpretations to more general ones later on (Lury \& Wakeford, 2012). The observations and the collected material then enabled us to reflect on mobility as an "experienced and embodied practice of movement" (Cresswell, 2010, p. 19). The research team initially considered carrying out the observation during Spring 2020. However, the plan was postponed due to the Coronavirus pandemic outbreak in February 2020, which had a serious impact on everyday life. This also became very noticeable to the researchers during the occasional park visits. The situation changed slightly in summer, mostly after people started their summer vacations and spending more time outdoors. Yet, the pandemic was likely affecting people's use of space during our observation, like other aspects of daily life.

\section{Results}

The results from the survey revealed that children are not only most observed in the sunken lawn (compared to canals and ponds) but also compared to the other age groups, this group was mentioned as the most active group around it. Half of the respondents confirmed children's presence around the sunken lawn. The numbers for the canals and ponds are $42 \%$ and $44 \%$ respectively. Moreover, the families living with children ( 68 out of 328 households) use the sunken lawn area together with kids more frequently than other types of BGS. The percentages of families visiting BGS with kids at least a few times per month are $74 \%$ for the sunken lawn, $67 \%$ for ponds, and $63 \%$ for canals.

After gaining a general impression of the park as a potential area for children's activities, we took the study further to explore if the park provided children with BGS-related play affordance features highlighted by Lerstrup and Konijnendijk van den Bosch (2017). Fire was the only class we excluded from this study, due to not considering it as a direct affordance feature of BGS. The assessment result (easier to be read together with Figure 2) indicates that the sunken lawn contains a large open ground that is a flat, relatively smooth surface to run, drive, or walk on. Different parts of the park provide sloping terrain for children to roll, slide, or clamber. These features are prominent in the hills and around the large bioswale. Behind the large hill (across the playground), around the dry pond and large wet pond, dense natural areas with different trees and vegetation are situated. Such places offer shelters and shielded places to hide or use as a frame. In the dry pond, along the large bioswale, and around the large pond, several concrete objects serve as rigid fixtures offering children the possibilities to climb, balance, and jump. Due to the presence of large amounts of vegetation, and especially those with more flexible parts such as branches as non-rigid attached objects (moving fixtures), there are some possibilities to swing but not much to sway, seesaw, and spin. Various types of bio-waste like coarse, woody debris, and fallen leaves provide children with graspable detached objects (movable and countable) to arrange, modify, or use as tools like props and treasures. Due to the location of the sunken lawn in the downstream part of the stormwater system, the soil moisture is usually higher than in other parts of the area. It is even higher in the lower parts of the lawn like inside the bioswales. Hence, there are usually mouldable materials (movable and not countable) available for children to dig, move, mould, and smear, depending on weather conditions. Plenty of water is available for children to pour, mix, splash, and float things on. However, the amount is fluctuating. The wet ponds are usually full of water. Other elements of the canals, dry pond, bioswales, and the entire lawn, depending on the time and intensity of rain, may temporally hold some water too. Different kinds of animals, such as birds and worms, are occasionally in the area. These creatures may create some events for children (i.e., to look for, chase, handle, and care for).

Following the mentioned results, we carried out observational studies by focusing on exploring if and how children in the park actualise the above-mentioned possibilities for play. The observational results come from tracing users, while the observer was mostly sitting on the only two benches available, which are in sight of the study area. Pink (2012) explains that places provide a template for practice and to understand the pattern of practice, understanding a place through a series of routes, rather than as a bounded locality, is essential. Being in an urban environment is formed along paths rather than in places, and places are shaped by coming and going to and from different locations and situations, i.e., through movement (Ingold, 2008). Here we applied a tracing method which helped us relate the users' practices to a wider environment. The tracing maps are illustrated in Figure 5 and will be discussed later, together with the information documented through field notes and sketches. Each map has been developed on a different occasion and is tagged with the observation date and time performed in July and August 2020. The pattern of people's movements in or around the studied area is presented with red lines. Each user is given a number in red. Family gatherings are shown with numbers in black. The lines specifically representing children's movements are marked with yellow circles. The perimeter of the circle is shown in yellow if the child was only a passer-by and the circle is filled in yellow if the child stayed and performed in the area.

\section{Discussion}

This study researches the potential multi-functionality of BGS in terms of possibilities to be used as children's playscapes in Augustenborg and explores attributes that influence the actualisation of those possibilities. The discussion will partly reflect on the potential for co-benefits or conflict between goals in ecological and social sustainable development and partly challenge the discourse 


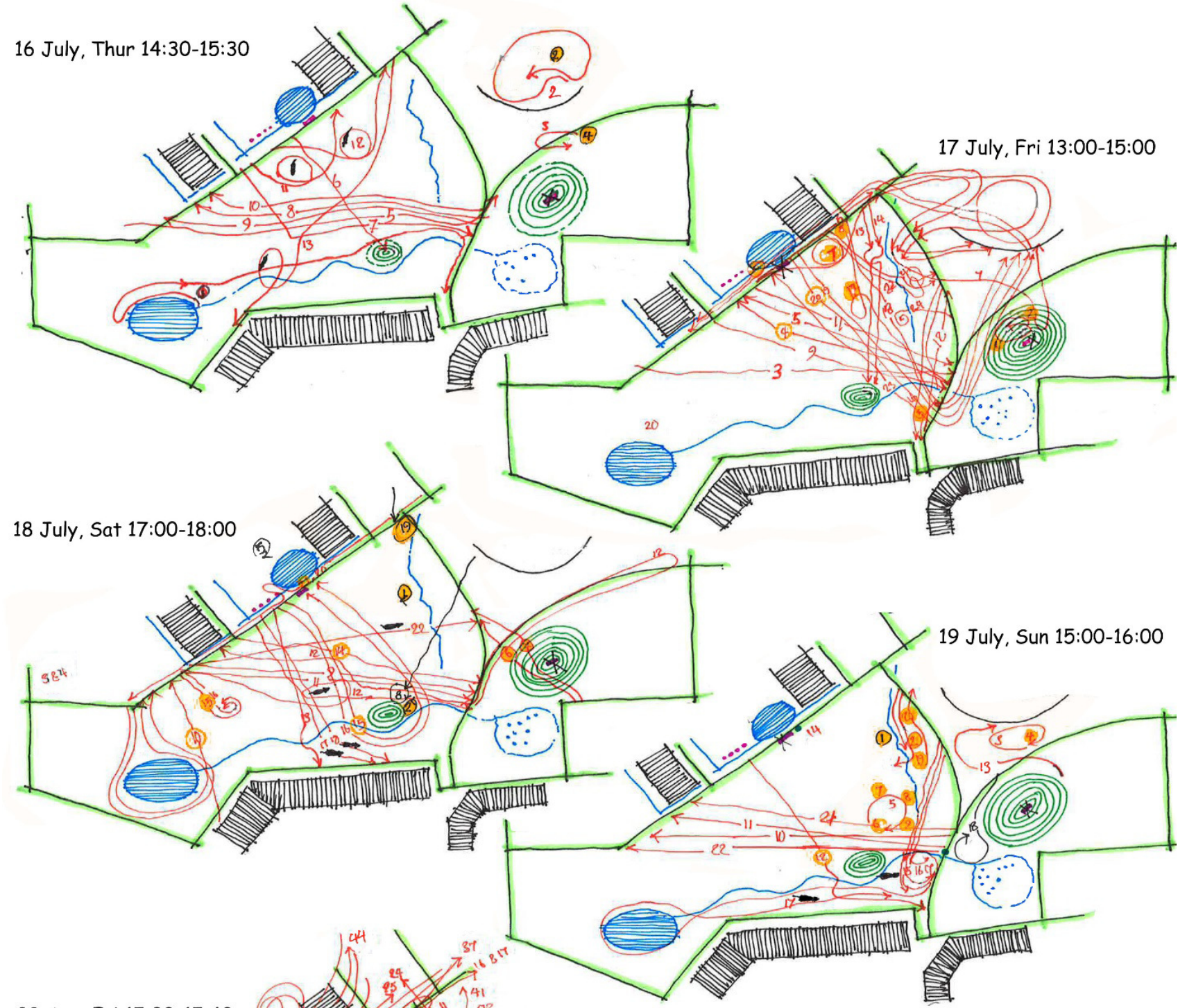

28 Aug, Fri 15:00-15:40

Part 1

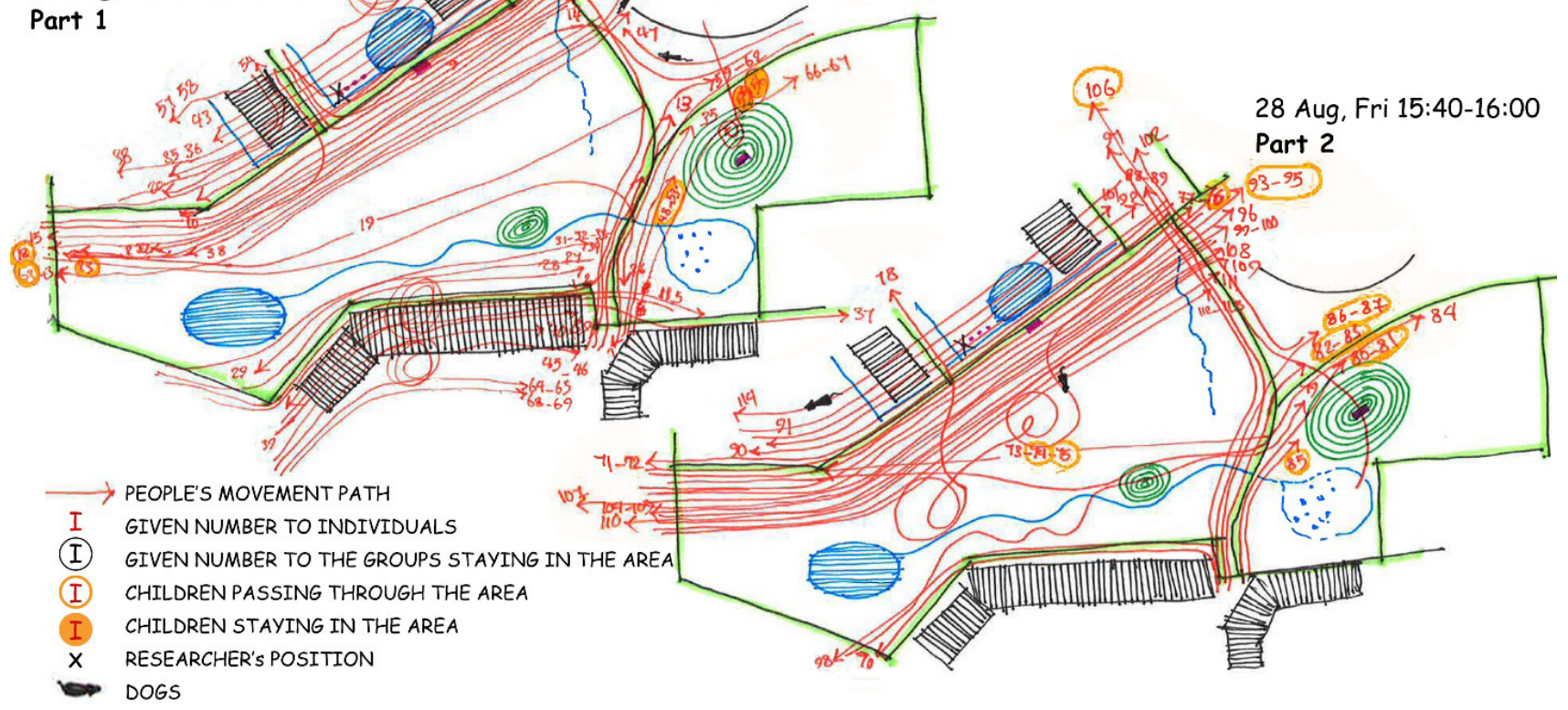

Figure 5. Tracing maps from field studies, July-August 2020. 
that it is possible to fill diminishing urban open space with added layers of functions without radically lowering the quality of place.

The result from the survey shows that, according to the respondents, the BGS in Augustenborg afford some degree of interaction with children. It indicates that children's presence is the highest for the sunken lawn that covers a large share of the park. The children-related, strategically planned land uses around the park such as the kindergarten, school, playground, and open sports fields also acknowledge the possible frequent presence of children within the proximity of the park. Studying the park by assessing the BGS-related play affordance features, with a reviewed affordance-based assessment tool, also revealed a wide range of play potentials in the park. The result indicated promising play potential for a variety of children's activities. However, the potentials per se cannot guarantee the use of a place by children. This fact stood out while exploring the park through observations and looking for whether and how children interact with BGS. The results of observations are partially presented in Figure 5.

The observational result showed very different dynamics at the place in different visits. Temporal changes largely influenced the number of people and their behavioural patterns. The use of the area altered with i.e., how warm it was, how windy it was, if it was rainy, which day (weekday or weekend) or which season (vacation time or school time) it was, etc. The sunken lawn was mainly used as a shortcut for commuting distance and travel time reduction. This function could be affected by how wet the lawn was (i.e., on rainy days). The commuting tempo was quite high in this area. In general, the area looked like it was being used as a transition area in which, during working days, the pace of movement was quite high. The area was also very popular with dogs. No dog could keep from exploring the lawn. However, although BGS offered many possibilities for play in the park, children's use of BGS affordance features was limited. Following, we discuss possible explanations based on the observational study.

First, children were most often controlled by authority figures like parents. It became clear how their use patterns were influenced by their parents' use of space. Families with kids only recognised the playground as their main play destination. If the adult did not spend time in other parts, the children did not get involved with other play features either and the sunken lawn remained an isolated green island, absent of children. If the natural play values have not been recognised by the authority figures, how will children be able to discover them, when they have not been given possibilities to spend time in other parts? For children, experiencing an environment requires being in the place and spending time there. Without that, it would be difficult to develop visual perceptions, which according to Heft $(2010$, p. 16) "is a process of detecting what is immediately in view." As observed, children were interested in
BGS affordance features in the area, but the matter of concern was having a chance for engagement. Whenever children followed the authority figures to the playground, even if they walked fast, every chance a child could get resulted in interacting with the nearest terrain change. For example, a little boy was following his mother on his mini-scooter. Suddenly, he stopped and left the miniscooter on the sidewalk. He jumped onto the lawn, bent over, and put his hand inside the pipe underneath the road. After a few seconds, he walked back toward the mini-scooter and left the area. Another example was a little girl walking with her mother towards the playground. She turned her head towards the lawn and immediately decided not to walk straight anymore. She went into the lawn, played with the slopes of the little bioswale, chased some birds further down, and finally continued walking towards the playground.

Interestingly, excepting the open ground part of the park, the rest of the BGS features in the area are far from passer-by's sights. There is almost an impression that the purpose behind designing the park was not to encourage people to stay there. The entire park is equipped with only two benches, placed far from the obvious terrain changes. This means there was no furniture for adults to sit comfortably and let the children discover the potential affordances while watching them carefully. While affordances are shaped by individual capabilities such as interest (particularly for younger children), they are also affected by external factors such as their authority figures, who are in turn affected by their own affordances and values (e.g., habits, culture, time, etc.). Another observation was that even if children passed by the wet pond, they did not interact with the water because it was either not detected or not attractive. We know that children's interactions with water features are influenced by different parameters such as age, weather, and localities (i.e., Bozkurt, Woolley, \& Dempsey, 2019; Kytta, 2002). Yet, it also depends on the socio-cultural practices of authority figures (i.e., the norms and considerations that affect children's perception of affordances largely; Kytta, 2004).

Temporal changes also influenced children's use of BGS in different ways. For example, at weekends, families spent more time at the park. They usually had two favourite spots to gather, close to the small bioswale and the small hill. As mentioned before, we excluded the feature 'fire' from our analysis through the assessment tool. Interestingly, in the observation, fire showed up as a strong unexpected and indirect affordance feature of BGS for family gatherings around their favourite spots. This might be due to reasons related to the microclimate, for example, because of the trees or pleasant humidity. Family gatherings provided an opportunity for the children to stay on the lawn and actualise the potential affordances. By observing a few gathering occasions, we realised children engage with the materiality of BGS in various ways. Mostly, subtle uneven surfaces, as well as surfaces of the small bioswale where digging was 
possible, were found to be more attractive for younger children. The lawn only attracted middle children when combined with external detached objects like bicycles (to ride and accelerate) or with other internal attached objects like tree branches (to swing, depending on the child's size, weight, and skills).

Furthermore, children engage with an urban environment as a whole and not necessarily only with those areas that are specifically allocated for their use (Jansson, Sundevall, \& Wales, 2016); the spatial configuration and design of an interesting place will capture their attention. While the designed play environments attract children more, they might also make them less motivated to look for affordances provided by places that are not specifically designed for play. If they do not get the chance or motivation to get closer to BGS, they will not recognise their additional natural play potentials. This partially explains why only the small bioswale and the large hill close to the playground were used by children and mostly by the younger children visiting the playground.

Moreover, the results showed how various relations between the environment and human behaviours affect affordances. The relation children establish with the environment is complex and affected by socio-ecological structures (Badland et al., 2016). Play affordances do not always occur directly. They may arise sequentially as nested affordance (Gaver, 1991), relationally as carried affordance, related to personal background (Kopljar, 2016), or compositionally as 'synergistic affordance,' which is the outcome of coincidental actions (Mottaghi et al., 2020). When some people decide to leave picnic trash on the lawn, it is not only due to psychological reasons related to habits or cultural differences, but possibly also to spatial reasons, such as not being close enough to the trash bins, thus introducing a lack of 'good' behaviour. Different behaviours may activate potential affordances through the mediators they generate. Affordances of a place set up human action possibilities as well as their consequences (Heft, 1989). Figure 6 shows an example. A family left the little hill without collecting their picnic trash. As affordances are unique to observer(s), a member of this family recognised the large bioswale as a perfect place to overturn the grill and extinguish the fire. This became interesting to a dog being walked on the lawn, but its owner tried to distract the dog from getting closer. The day after, more trash was added and scattered. Although this spot is one of the two favourite spots for a group gathering, no one was even getting close. The wasted food attracted the birds and turned animals into the main users of the lawn. Their presence mediated the interaction between the park and children and actualised some play affordances as events. This shows how a complex situation may result in play affordance for children.

There seems to be considerable potential for cobenefits when ecological values such as BSG and social values such as children's playscapes collaborate in space. This study shows that Augustenborg Park was used by children as recreational grounds and somewhat as playscapes, but there were limits in the design to attract children to physically engage with BGS since they are not inherently assured to be used by children. To increase the play values, the sociality and spatiality would need to be considered together and included in the planning and design guidelines. Children need to be considered as an important target group in stormwater management since what functions for them usually does for others as well (Shaw et al., 2015). To support children's everyday needs, understanding their perspectives and considering their experiences in the process of design and management of urban spaces is crucial (Horelli, 1998).

In the current situation of climate change, there are arguments to develop more urban open green spaces for managing stormwater. Increasing knowledge on how built and social structures influence the everyday use of BGS would support decision-makers in promoting larger benefits of BGS. In the densification trend, urban open spaces are instead diminishing and being assigned to contain solutions for an adding amount of everyday functions such as bicycle parking, waste sorting, BGS, and play spaces. Some of these functions can be defined in spatial terms, while other functions are more dependent on qualitative values that also have spatial demands and are hence difficult to define in spatial terms. In the overall densification trend, it is important to acknowledge that there is a limit to how spatially small the urban open spaces can be to-through a good design-contain all the needed functions for adequate and sustainable
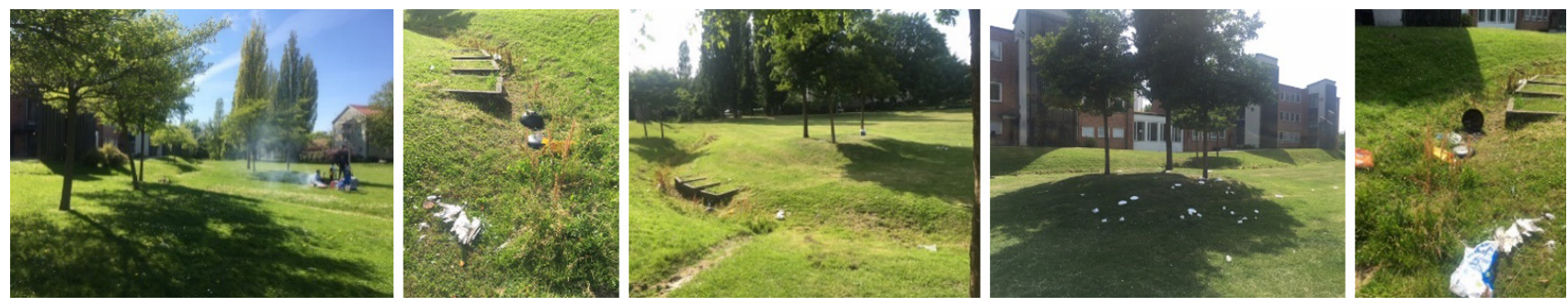

Figure 6. Example of relations between human actions and affordances of BGS. From left to right: the small hill (one of the two main popular spots for family gatherings); 18 July, inside the large bioswale after one family left; 18 July, park view afterwards; 19 July, trash added and spread out, no family uses this spot anymore, behind the camera, birds gathered around the food waste and a few children run to chase them; and 19 July, more trash in the swale. 
urban life. Otherwise, the consequences of rapid urbanisation will limit the possibilities for children's activities to take place in urban space.

\section{Conclusions}

This research shows that, due to diversity in their nature, BGS offer a variety of potential play affordances to children in Augustenborg Park. However, the study also shows that actualised play affordances were limited and children did not really engage with BGS playing features. Actualised affordances happen at different levels as they are perceived, utilised, and shaped (Kytta, 2002). Any interruption in the process affects the actualisation of affordances. It is not enough to focus only on the quality of BGS play features. Urban planners need to pay attention to spatial design and hierarchy. Urban environments with BGS need to be designed in a way to help users to identify it as a place to stay in, rather than to just pass through. Also, instead of making the affordances offered by BGS compete with other affordancesoffered by children places, like playgrounds-it is necessary to make them complimentary of each other. This can happen by producing a series of places that are on similar levels of importance, as well as making BGS affordances more accessible. A rich spatial integration creates a dialogue and symmetrical relations between different places. It not only expands dimensions of play destinations but also provides opportunities for BGS to be perceived and utilised as diverse places to spend time for both children and their authority figures.

An environment might bring perfect play values to children, but not fit the socio-cultural structure of the environment (Ergler, Kearns, \& Witten, 2013). Older children are usually able to make their own discovery and adventures in a place, but younger children's use of a place is largely influenced by the socio-cultural practices of authority figures. Hence, authority figures should be considered in the planning process, in terms of allowing them to recognise the offered affordances. This occurs through creating more opportunities for interaction with BGS, for example by adding seating such as benches in relevant areas. Attracting parents to spend time near BGS also gives children time to explore different niches of the environment and to find additional play affordances. This study also shows that play affordances are not always arrangeable. On-going temporal changes and constant sequential and synergistic effects influence the affordance of a given environment. Moreover, individual affordances alter with individual changes as children develop in size, viewpoint, and skill (Gibson, 1979; Heft, 1988).

Children's interaction with nature enhances their cognitive development and health. Since BGS offer various ecological play affordances, it is well worth urban planners putting effort into the actualisation of BGS play affordances, which requires considering children in the early stages of planning. Increasing knowledge of the relations between children and existing urban environments helps the process of decision-making to focus more on how to provide children with a better urban environment to play in. We saw how two different settings of a similar design, like the bioswale, might create different affordances in terms of both stormwater resilience and affording children to interact with the urban landscape. This study highlights a recommendation for maximising the use, spatial, and physical characteristics of BGS, which all need to be discussed together and in relation to the sociality of the environment. This study also shows that, due to the complexity of exploring the relationship between children and their environment, combining different methods can improve the quality of research. On our way to more effective policies and investment opportunities, through which BGS and children playscapes support one another, we still need to improve our socio-spatial understanding of the interaction. Hence, further research is required to recognise what kinds of behavioural patterns BGS may trigger in children and how they respond to children's everyday needs.

\section{Acknowledgments}

The research was financially supported by FORMAS (Swedish Research Council for Environment, Agricultural Sciences, and Spatial Planning; Research project: Sustainable Urban Flood Management. Grant number: 942-2015-149) and Sweden Water Research AB (Research project: Design of Blue-Green Spaces. Project number: 500301).

\section{Conflict of Interests}

The authors declare no conflict of interests.

\section{References}

Badland, H., Kearns, R., Carroll, P., Oliver, M., Mavoa, S., Donovan, P., . . Witten, K. (2016). Development of a systems model to visualise the complexity of children's independent mobility. Children's Geographies, 14(1), 91-100. https://doi.org/10.1080/14733285. 2015.1021240

Baeten, G. (2012). Normalising neoliberal planning: The case of Malmö, Sweden. In T. Tasan-Kok and G. Baeten (Eds.), Contradictions of neoliberal planning (pp. 21-42). Dordrecht: Springer.

Berg, L.-E. (1992). Den lekande människan: En socialpsykologisk analys av lekandets dynamik [The playful human being: A social psychological analysis of the dynamics of play]. Lund: Studentlitteratur.

Bozkurt, M., Woolley, H., \& Dempsey, N. (2019). Children's interactions with water in city centres: A case study from Sheffield, UK. Landscape Research, 44(6), 671-687. https://doi.org/10.1080/01426397. 2018.1518518 
Chawla, L. (2015). Benefits of nature contact for children. Journal of Planning Literature, 30(4), 433-452. https://doi.org/10.1177/0885412215595441

Cresswell, T. (2010). Towards a politics of mobility. Environment and Planning D: Society and Space, 28(1), 17-31. https://doi.org/10.1068/d11407

Emilsson, T., \& Sörensen, J. (2020). Gröna tak, dagvatten och hållbarhet-Augustenborg som forskningsarena [Green roofs, stormwater and sustainability: Augustenborg as an arena of research]. In M. Månsson \& B. Persson (Eds.), Ekostaden AugustenborgErfarenheter och lärdomar [Eco-city Augustenborg: Experiences and learnings] (pp. 164-173). Malmö: Arkus.

Ergler, C. R., Kearns, R. A., \& Witten, K. (2013). Seasonal and locational variations in children's play: Implications for wellbeing. Social Science \& Medicine, 91, 178-185. https://doi.org/10.1016/j.socscimed.2012. 11.034

Faskunger, J. (2007). Den byggda miljöns påverkan på fysisk aktivitet [The influence of built environment on physical activity]. Stockholm: Strömberg Distribution. Retrieved from https://www. folkhalsomyndigheten.se/contentassets/bd4c8de3a 04b4d20ac7e0f0385193663/byggda-miljonspaverkan-fysisk-aktivitet.pdf

Gaver, W. W. (1991). Technology affordances. In S. P. Robertson, G. M. Olson, \& J. S. Olson (Eds.), Proceedings of the SIGCHI Conference on Human Factors in Computing Systems (pp. 79-84). New York, NY: Association for Computing Machinery. https://doi.org/ 10.1145/108844.108856

Gehl, J., \& Svarre, B. (2013). How to study public life. Washington, DC: Island Press.

Gibson, J. J. (1979). The ecological approach to visual perception. Boston, MA: Houghton Mifflin.

Heft, H. (1988). Affordances of children's environments: A functional approach to environmental description. Children's Environments Quarterly, 5(3), 29-37.

Heft, H. (1989). Affordances and the body: An intentional analysis of Gibson's ecological approach to visual perception. Journal for the Theory of Social Behaviour, 19, 1-30.

Heft, H. (2010). Affordances and the perception of landscape: An inquiry into environmental perception and aesthetics. In C. Ward Thompson, P. Aspinall, \& S. Bell (Eds.), Innovative approaches to researching landscape and health: Open space: People space 2 (pp. 9-32). New York, NY: Routledge.

Heft, H. (2013). Environment, cognition, and culture: Reconsidering the cognitive map. Journal of Environmental Psychology, 33, 14-25. https://doi.org/ 10.1016/j.jenvp.2012.09.002

Holgersen, S., \& Malm, A. (2015). 'Green fix' as crisis management. Or, in which world is Malmö the world's greenest city? Geografiska Annaler Series B: Human Geography, 97(4), 275-290. https://doi.org/ 10.1111/geob.12081
Horelli, L. (1998). Creating child-friendly environments: Case studies on children's participation in three European countries. Childhood: A Global Journal of Child Research, 5(2), 225-239. https://doi.org/10.1177/ 0907568298005002008

Ingold, T. (2008). Bindings against boundaries: Entanglements of life in an open world. Environment and Planning A: Economy and Space, 40(8), 1796-1810. https://doi.org/10.1068/a40156

Jansson, W., Sundevall, E., \& Wales, M. (2016). The role of green spaces and their management in a child-friendly urban village. Urban Forestry \& Urban Greening, 18, 228-236. https://doi.org/10.1016/j. ufug.2016.06.014

Jenks, M., Burton, E., \& Williams, K. (1996). Compact cities and sustainability: An introduction. In E. Burton, M. Jenks, \& K. Williams (Eds.), The compact city: A sustainable urban form? (pp. 2-6). London: Taylor \& Francis.

Karsten, L. (2014). From Yuppies to Yupps: Family gentrifiers consuming spaces and re-inventing cities. Tijdschrift Voor Economische En Sociale Geografie, 105(2), 175-188. https://doi.org/10.1111/tesg. 12055

Karsten, L., \& Felder, N. (2015). Parents and children consuming the city: Geographies of family outings across class. Annals of Leisure Research, 18(2), 205-218. https://doi.org/10.1080/11745398.2015.1011679

Kopljar, S. (2016). How to think about a place not yet: Studies of affordance and site-based methods for the exploration of design professionals' expectations in urban development processes. Lund: Department of Architecture and Built Environment, Faculty of Engineering, Lund University.

Kylin, M., \& Bodelius, S. (2015). A lawful space for play: Conceptualizing childhood in light of local regulations. Children, Youth \& Environments, 25(2), 86-106. https://doi.org/10.7721/chilyoutenvi.25.2.0086

Kytta, M. (2002). Affordances of children's environments in the context of cities, small towns, suburbs and rural villages in Finland and Belarus. Journal of Environmental Psychology, 22(1/2), 109-123.

Kytta, M. (2004). The extent of children's independent mobility and the number of actualized affordances as criteria for child-friendly environments. Journal of Environmental Psychology, 24(2), 179-198. https://doi.org/10.1016/s0272-4944(03)00073-2

Lerstrup, I., \& Konijnendijk van den Bosch, C. (2017). Affordances of outdoor settings for children in preschool: Revisiting Heft's functional taxonomy. Landscape Research, 42(1), 47-62. https://doi.org/ 10.1080/01426397.2016.1252039

Lury, C., \& Wakeford, N. (2012). Inventive methods: The happening of the social. Abingdon: Routledge.

Malmö stad. (2019). Statistik för Malmös områden [Statistics of Malmö urban area]. Malmö stad. Retrieved from https://malmo.se/Fakta-ochstatistik/ Statistik-for-Malmos-omraden.html 
Martensson, F., Jansson, M., Johansson, M., Raustorp, A., Kylin, M., \& Boldemann, C. (2014). The role of greenery for physical activity play at school grounds. Urban Forestry \& Urban Greening, 13(1), 103-113. https://doi.org/10.1016/j.ufug.2013.10.003

Martinez Avila, C., Hanson, H., \& Alkan Olsson, J. (2020). Deltagande och medbestämmande i Ekostaden Augustenborg [Participation and co-determination in the Eco-city Augustenborg]. In M. Månsson \& B. Persson (Eds.), Ekostaden AugustenborgErfarenheter och lärdomar [Eco-city Augustenborg: Experiences and learnings] (pp. 45-52). Malmö: Arkus.

Mottaghi, M., Kärrholm, M., \& Sternudd, C. (2020). Blue-green solutions and everyday ethicalities: Affordances and matters of concern in Augustenborg, Malmö. Urban Planning, 5(4), 132-142. https://doi. org/10.17645/up.v5i4.3286

Nilsson, P.-A., Nilsson, M. O., Persson, B. (2020). Augustenborg-En förebild för klimatpositiv välfärd? [Augustenborg: A role model for climate positive welfare?]. In M. Månsson \& B. Persson (Eds.), Ekostaden Augustenborg-Erfarenheter och lärdomar [Eco-city Augustenborg: Experiences and learnings] (pp. 286-293). Malmö: Arkus.

Nordström, M. (2014). Planning for children's health and outdoor activities in Swedish cities; The need for a child-friendly perspective. In A. Schærström, S. H. Jørgensen, T. Kistemann, \& Å. Sivertun (Eds.), Geography and health: A Nordic outlook (Chapter 5; pp. 60-68). The Swedish National Defence College: Stockholm.

Pagels, P., Raustorp, A., De Leon, A. P., Martensson, F., Kylin, M., \& Boldemann, C. (2014). A repeated measurement study investigating the impact of school outdoor environment upon physical activity across ages and seasons in Swedish second, fifth and eighth graders. Bmc Public Health, 14(1), 1-9. https://doi. org/10.1186/1471-2458-14-803

Pink, S. (2012). Situating everyday life: Practices and places. London: Sage Publications.

Refshauge, A. D., Stigsdotter, U. K., Lamm, B., \& Thorleifsdottir, K. (2015). Evidence-based playground design: Lessons learned from theory to practice. Landscape Research, 40(2), 226-246. https://doi.org/10.1080/ 01426397.2013 .824073
Shaw, B., Bicket, M., Elliott, B., Fagan-Watson, B., Mocca, E., \& Hillmn, M. (2015). Children's independent mobility: An international comparison and recommendations for action. London: Policy Studies Institute.

Sörensen, J., \& Emilsson, T. (2019). Evaluating flood risk reduction by urban blue-green infrastructure using insurance data. Journal of Water Resources Planning and Management, 145(2), 04018099. https:// doi.org/10.1061/(asce)wr.1943-5452.0001037

Stahre, P. (2008). Blue-green fingerprints in the city of Malmö, Sweden: Malmö's way towards a sustainable urban drainage. Malmö: Va syd.

Statistics Sweden. (2005). Statistical yearbook of Sweden 2005 (Volume 91). Örebro: Statistics Sweden. Retrieved from http://share.scb.se/ov9993/data/ historisk\%20statistik//SOS\%201911-/Statistisk\%20 \%C3\%A5rsbok\%20(SOS)\%201914-2014/Statistiskarsbok-for-Sverige-2005.pdf

Statistics Sweden. (2018). Grundskolor och friytor: Nationell kartläggning och uppföljning av grundskoleelevers tillgång till friytor 2014-2017 [Elementary schools and open spaces]. Stockholm. SCB. Retrieved from https://www.boverket.se/ contentassets/7f6b1586a5504fcfa11ea370f73b2 b05/rapport-grundskolor-och-friytor.pdf

Tägil, T. (2020). Det planerade folkhemmet [The planned people's home]. In M. Månsson \& B. Persson (Eds.), Ekostaden Augustenborg-Erfarenheter och lärdomar [Eco-city Augustenborg: Experiences and learnings] (pp. 64-75). Malmö: Arkus.

Tykesson, T. L., \& Ingemark Milos, A. (2001). Bostadsmiljöer i Malmö: Inventering. D. 1 1945-1955 [Residential areas in Malmö: An inventory. P. 1 1945-1955]. Malmö: Malmö kulturmiljö.

UN. (2019). World urbanization prospects: The 2018 revision (ST/ESA/SER.A/420). New York, NY: United Nations.

UN Office for Disaster Risk Reduction. (2019). 2018 Annual report. Geneva: United Nations. Retrieved from https://www.undrr.org/publication/unitednations-office-disaster-risk-reduction-2018-annualreport

Woolley, H., \& Lowe, A. (2013). Exploring the relationship between design approach and play value of outdoor play spaces. Landscape Research, 38(1), 53-74. https://doi.org/10.1080/01426397.2011.640432

\section{About the Authors}

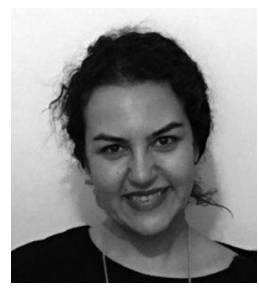

Misagh Mottaghi is a PhD Student of Architecture at Lund University, Sweden. She is conducting research for Sweden Water Research and her research deals with blue-green infrastructure. She applies relational perspectives to explore how BGS affect the use of public space in everyday life. She is a Guest Lecturer in different courses and teaches sustainable urban design studios. 


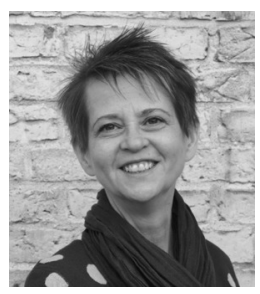

Maria Kylin is Senior Lecturer of Landscape Architecture and responsible for pedagogics and courses at the Department of Landscape Architecture, Planning and Management, Swedish Agricultural University, Alnarp, Sweden. She is engaged in the teaching and program development of several landscape educations. Her research revolves around children's use and experience of open space and how this can be translated and used in architect and planning practices.

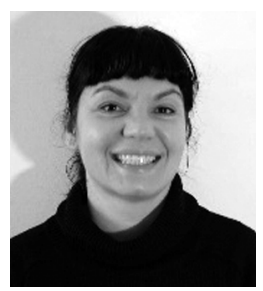

Sandra Kopljar is an Associate Senior Lecturer at the Department of Architecture and Built Environment, Faculty of Engineering, Lund University, Sweden. Her research interest revolves around urban development and design processes connected to design professionals' methodology and pedagogy. These themes are investigated in relation to design, artistic research, and research on the handling of everyday actions and strategies concerning the built environment.

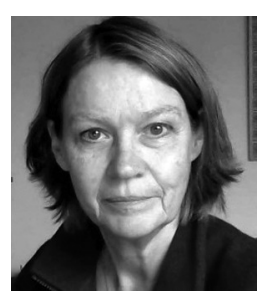

Catharina Sternudd is Senior Lecturer of Architecture and Head of the Department of Architecture and Built Environment at the Faculty of Engineering, Lund University, Sweden. She is also a Coordinator of Urban Arena, a platform that gathers research on sustainable urban development at Lund University. Her research revolves around urban design with a special focus on environmental support for sustainable everyday practices, such as walking and children's independent psychical activity. 